\title{
5-Aminoimidazole-4-carboxamide ribonucleoside treatment improves glucose homeostasis in insulin-resistant diabetic (ob/ob) mice
}

\author{
X. M.Song ${ }^{1}$, M. Fiedler ${ }^{2}$, D. Galuska ${ }^{1}$, J.W. Ryder ${ }^{1}$, M. Fernström ${ }^{3}$, A. V. Chibalin ${ }^{3}$, H. Wallberg-Henriksson ${ }^{1}$, \\ J.R.Zierath ${ }^{1}$ \\ ${ }^{1}$ Department of Physiology and Pharmacology, Karolinska Institutet, Stockholm, Sweden \\ ${ }^{2}$ Biovitrum, Department of Pharmacology, Uppsala, Sweden \\ ${ }^{3}$ Department of Clinical Physiology, Karolinska Hospital, Stockholm, Sweden
}

\section{Abstract}

Aims/hypothesis. The 5'AMP-activated protein kinase is an important mediator of muscle contractioninduced glucose transport and a target for pharmacological treatment of Type II (non-insulin-dependent) diabetes mellitus. The 5'AMP-activated protein kinase can be activated by 5-aminoimidazole-4-carboxamide ribonucleoside. We hypothesised that 5-aminoimidazole-4-carboxamide ribonucleoside treatment could restore glucose homeostasis in $o b / o b$ mice. Methods. Lean and ob/ob mice were given 5-aminoimidazole-4-carboxamide ribonucleoside $(1 \mathrm{mg} \cdot \mathrm{g}$ body $\mathrm{wt}^{-1} \cdot$ day $^{-1}$ s.c) or $0.9 \% \mathrm{NaCl}$ (vehicle) for 1-7 days. Results. Short-term 5-aminoimidazole-4-carboxamide ribonucleoside treatment normalised glucose concentrations in $o b / o b$ mice within $1 \mathrm{~h}$, with effects persisting over $4 \mathrm{~h}$. After 1 week of daily injections, 5-aminoimidazole-4-carboxamide ribonucleoside treatment corrected hyperglycaemia, improved glucose tolerance, and increased GLUT4 and hexokinase II protein expression in skeletal muscle, but had deleterious effects on plasma non-esterified fatty acids and triglycerides. Treatment with 5-aminoimidazole-4-carboxamide ribonucleoside increased liver glycogen in fasted and fed $o b / o b$ mice and muscle glycogen in fasted, but not fed $o b / o b$ and lean mice. Defects in insulin-stimulated phosphatidylinositol 3-kinase and glucose transport in skeletal muscle from $o b / o b$ mice were not corrected by 5-aminoimidazole4-carboxamide ribonucleoside treatment. While ex vivo insulin-stimulated glucose transport was reduced in isolated muscle from $o b / o b$ mice, the 5-aminoimidazole-4-carboxamide ribonucleoside stimulated response was normal.

Conclusion/interpretation. The 5-aminoimidazole-4carboxamide ribonucleoside mediated improvements in glucose homeostasis in $o b / o b$ mice can be explained by effects in skeletal muscle and liver. Due to the apparently deleterious effects of 5-aminoimidazole-4-carboxamide ribonucleoside on the blood lipid profile, strategies to develop tissue-specific and pathway-specific activators of 5'AMP-activated protein kinase should be considered in order to improve glucose homeostasis. [Diabetologia (2002) 45: 56-65]

Keywords Glucose transport, glycogen, lipids, insulin signalling, glucose tolerance, obesity, GLUT4, hexokinase II, glycogen synthase, myocyte enhancer factor 2 .
Received: 21 June 2001 and in revised form: 20 July 2001

Corresponding author: J. R.Zierath, Department of Physiology and Pharmacology, Integrative Physiology Karolinska Institutet, von Eulers väg 4, II, Stockholm, Sweden, e-mail: Juleen. Zierath@fyfa.ki.se

Abbreviations: AICAR, 5-aminoimidazole-4-carboxamide ribonucleoside; ZMP, 5-aminoimidazole-4-carboxamide ribonucleotide; AMPK, 5' AMP-activated protein kinase; ALAT, alanine aminotransferase; NEFA, non-esterified fatty acids; EDL, extensor digitorum longus; KHB, Krebs-Henseleit buffer; PI, phosphatidylinositol; MEF2, myocyte enhancer factor 2; TBE, Tris borate/EDTA
Type II (non-insulin-dependent) diabetes mellitus is one of the major causes of disability and death, these being due to the complications accompanying the disease, [1]. Today, the therapeutic tools commonly utilised to treat Type II diabetes mellitus include diet, exercise, anti-diabetic drugs and insulin treatment. These therapies have been successful in keeping metabolic control within an acceptable range. However, the management of Type II diabetes mellitus has failed with respect to the prevention of the disease 
$[2,3]$. Furthermore, multiple therapeutic strategies are needed to fully normalise metabolic control and prevent the development of severe complications in the cardiovascular system, nervous system and the renal system [4]. Therefore, effective intervention strategies need to be developed to reduce the incidence of Type II diabetes mellitus and the resulting complications.

Physical activity and exercise training improve substrate utilisation and insulin sensitivity, which in turn can lower blood glucose and lipid concentrations in the diabetic patient $[5,6]$. The benefits of regular exercise on glucose homeostasis are indisputable and one of the major challenges of health care professionals is to improve patient compliance with exercise prescriptions. Many Type II diabetic patients are sedentary and might be unable to increase their physical activity due to chronic complications of the disease or other associated medical conditions [7, 8]. Thus, pharmacological intervention with compounds designed to mimic the exercise-response on glucose uptake or fatty acid oxidation could help in the management of metabolic abnormalities associated with Type II diabetes mellitus.

5-aminoimidazole-4-carboxamide ribonucleoside (AICAR) is an adenosine analogue that can be absorbed into intact hepatocytes, adipocytes and skeletal muscle and is phosphorylated to form 5-aminoimidazole-4-carboxamide ribonucleotide (ZMP), the monophosphorylated derivative that mimics the effects of AMP on 5'AMP-activated protein kinase (AMPK) without affecting ATP or ADP content [9-12]. AMPK is considered a master switch, regulating key proteins in metabolic pathways known to control hepatic fatty acid oxidation and ketogenesis, lipogenesis and triglyceride synthesis, adipocyte lipolysis, modulation of insulin secretion from the pancreatic beta cells and skeletal muscle fatty acid oxidation [13]. AMPK is also thought to be an important mediator of the contraction-induced (insulin-independent) GLUT4 translocation and glucose transport in skeletal muscle [9, 14-16]. Numerous studies have now shown that AICAR exposure increases AMPK activity in skeletal muscle [9,14-19]. The administration of AICAR increases GLUT4 protein expression, hexokinase activity, glucose transport and glycogen content in muscle $[9,14-19]$, presumably by activating AMPK. Furthermore, AICAR inhibits gluconeogenesis in liver, probably by inhibiting fructose-1,6bisphosphatase [20].

We measured the short-term and long-term effects of in vivo AICAR-treatment on glucose homeostasis in diabetic $o b / o b$ mice. Furthermore, isolated skeletal muscle from $o b / o b$ mice was exposed to AICAR and in vitro glucose uptake was measured.

\section{Materials and methods}

Animals. Lean (C57BL) and ob/ob mice (8-10 weeks old) were obtained from B\&K Universal (Sollentuna, Sweden). All mice were maintained under a 12-h light/12-h dark cycle and had free access to water and standard rodent chow. The mice were given a subcutaneous injection with AICAR $\left(1 \mathrm{mg} \cdot \mathrm{g}\right.$ body $\mathrm{wt}^{-1} \cdot$ day $^{-1}$; as a $10 \%$ solution in $\left.0.9 \% \mathrm{NaCl}\right)$ or $0.9 \% \mathrm{NaCl}$ (vehicle), administered at $0900 \mathrm{~h}$ for 1-7 days. For the short-term and long-term (7-day) dosing studies, four groups of mice were studied: vehicle $(0.9 \% \mathrm{NaCl})$-treated lean mice $(n=20)$; AICAR-treated lean mice $(n=19)$; vehicle-treated $o b / o b$ mice $(n=19)$; AICAR-treated $o b / o b$ mice $(n=20)$. A physiological test of mice assigned to the longterm dosing study was done $24 \mathrm{~h}$ after the last treatment. An additional group of untreated lean $(n=8)$ and $o b / o b(n=8)$ mice were used for a short-term in vitro study to measure the direct effect of AICAR on glucose transport in isolated skeletal muscle. All protocols were approved by the Animal Ethical Committee.

Glucose tolerance test. Glucose $\left(3 \mathrm{~g} \cdot \mathrm{kg}\right.$ body wt. $\left.{ }^{-1}\right)$ was administered orally by gavage to conscious vehicle $(0.9 \% \mathrm{NaCl})$ or AICAR-treated mice. Blood was sampled through the tail vein before and $0.5,1,2$, and $3 \mathrm{~h}$ after a glucose administration. Blood glucose was analysed using a One-Touch glucose monitor (Lifescan, Milpitas, Calif., USA).

Blood chemistry analysis. Twenty-four hours after the last AICAR treatment, blood was sampled from the retro-orbis of the eye from fed mice. Plasma insulin concentrations were determined using a commercially available ELISA kit (Rat Insulin ELISA, Mercodia, Uppsala, Sweden) using rat insulin standards. Plasma non-esterified fatty acid (NEFA) was measured by an enzymatic fluorometric method (NEFA C; Wako, Neuss, Germany). Plasma triglyceride levels were determined fluorometrically using a commercially available kit (Triglycerides/ GB; Boehringer Mannheim, Indianapolis, Ind., USA). Plasma alanine aminotransferase (ALAT) was determined spectrophotometrically (Cobas Mira, Roche, Montclair, N. J., USA) using a commercially available ALT Unimate 3 kit (Roche, Basel, Switzerland).

Muscle incubations. Mice were anaesthetised by an injection $\left(0.2 \mathrm{ml}\right.$ of $2.5 \%$ solution $\cdot \mathrm{g}$ body wt. ${ }^{-1}$ i. p.) of Avertin (tribromoethanol, tertamyl alcohol, Aldrich, Milwaukee, Wis., USA), and isolated soleus and extensor digitorum longus (EDL) muscles were excised and utilised for in vitro incubations. All incubation media were prepared from a stock solution of Krebs-Henseleit buffer (KHB) which contained hydroxyethylpiperazine-ethanesulphonic acid (HEPES; 5 mmol/1; $\mathrm{pH} 7.2$, $30^{\circ} \mathrm{C}$ ) and $0.1 \%$ BSA (RIA Grade, Sigma, St. Louis, Mo., USA). The gas phase throughout all incubations was maintained at $95 \% \mathrm{O}_{2} / 5 \% \mathrm{CO}_{2}$. Soleus and EDL muscles were incubated for $30 \mathrm{~min}$ at $30^{\circ} \mathrm{C}$ in $\mathrm{KHB}$ supplemented with $20 \mathrm{mmol} / \mathrm{l}$ mannitol (pre-incubation media). Muscles were incubated in the absence or presence of $120 \mathrm{nmol} / \mathrm{l}$ insulin (Actrapid, Novo Nordisk, Bagsvaerd, Denmark), $2 \mathrm{mmol} / \mathrm{l} \mathrm{AICAR,} \mathrm{or} \mathrm{a} \mathrm{combi-}$ nation of insulin $(120 \mathrm{nmol} / \mathrm{l})$ and $\operatorname{AICAR}(2 \mathrm{mmol} / \mathrm{l})$.

Assessment of glucose transport activity. Following pre-incubation, muscles were incubated for $10 \mathrm{~min}$ at $30^{\circ} \mathrm{C}$, in $\mathrm{KHB}$ containing $20 \mathrm{mmol} / \mathrm{l}$ mannitol and the specific additions as described for each experiment. This incubation step was included to rinse glucose from the extracellular space of the muscle. Glucose transport was assessed at $30^{\circ} \mathrm{C}$, using 2-deoxyglucose 
[21]. Muscles were incubated for $20 \mathrm{~min}$ in $\mathrm{KHB}$ containing $1 \mathrm{mmol} / 1$ 2-deoxy-[1,2, $\left.{ }^{3} \mathrm{H}\right]$ glucose $(2.5 \mu \mathrm{Ci} / \mathrm{mmol})$, and $19 \mathrm{mmol} / \mathrm{l}$ mannitol $(26.3 \mu \mathrm{Ci} / \mathrm{mmol})$. 2-deoxyglucose uptake reflects glucose transport and not metabolism in mouse skeletal muscle when used under the present condition [21]. Muscles were processed as previously described [22]. Glucose transport activity is expressed as micromoles of glucose analogue accumulated per $\mathrm{ml}$ of intracellular water per hour.

Phosphotyrosine-associated phosphatidylinositol (PI) 3-kinase activity. Soleus or EDL muscles were incubated for $30 \mathrm{~min}$ in basal KHB media (no insulin or AICAR present), as described above under Muscle Incubations. Thereafter, muscles were incubated for $6 \mathrm{~min}$ in the absence or presence of insulin $(120 \mathrm{nmol} / \mathrm{l})$. Muscles were homogenised in $500 \mu \mathrm{l}$ lysis buffer as described [23] and solubilised by continuous stirring for $1 \mathrm{~h}$ at $4^{\circ} \mathrm{C}$. Following centrifugation $(12000 \mathrm{~g}$ for $10 \mathrm{~min}$ at $4{ }^{\circ} \mathrm{C}$ ). Protein was determined in the supernatant using a commercial kit (Bio-Rad, Richmond, Calif., USA). The supernatant $(500 \mu \mathrm{g})$ was immunoprecipitated overnight $\left(4^{\circ} \mathrm{C}\right)$ with an anti-phosphotyrosine antibody (Transduction Laboratories, Lexington, Ky., USA) coupled to protein A-sepharose (Pharmacia, Uppsala, Sweden). We assessed PI 3-kinase activity directly on the protein A-sepharose beads as described [24]. The bands corresponding to PI 3-phosphate were quantified using a PhosphoImager (Bio-Rad, Richmond, Calif., USA).

Glycogen and triglyceride analysis. Gastrocnemius muscle and liver were removed from anaesthetised mice and immediately frozen in liquid nitrogen. Glycogen content was measured fluorometrically on extracts of muscle or liver as described [22]. Results are expressed as $\mu \mathrm{mol}$ glucose $\cdot \mathrm{g}$ wet weight ${ }^{-1}$. Muscle and liver triglycerides were extracted using chloroform-methanol. Free glycerol was measured using Sigma triglyceride reagent (Sigma, St Louis, Mo., USA) and the reaction was read using a spectrophotometer $(540 \mathrm{~nm})$. Results are expressed as $\mu \mathrm{mol} \cdot \mathrm{g}$ wet weight ${ }^{-1}$.

Protein expression studies. Portions of the gastrocnemius muscle were polytron homogenised in $1.5 \mathrm{ml}$ ice-cold HES buffer (10 mmol/l HEPES, $1 \mathrm{mmol} / \mathrm{l}$ EDTA, sucrose $250 \mathrm{mmol} / \mathrm{l}, \mathrm{pH}$ 7.4). The muscle homogenates were subjected to centrifugation for $10 \mathrm{~min}$ at $12000 \cdot \mathrm{g}\left(4^{\circ} \mathrm{C}\right)$ and the supernatant was used to assess GLUT4, Hexokinase II or glycogen synthase protein content. Aliquots of muscle homogenates containing $20 \mu \mathrm{g}$ of protein were suspended in Laemmli buffer. Proteins were separated by SDS-PAGE (10\% resolving gel), transferred to polyvinylidenedifluoride membranes (Millipore, Bedford, Mass., USA), and blocked with $5 \%$ non-fat milk. Membranes were incubated in primary antibody overnight at $4{ }^{\circ} \mathrm{C}$. The polyclonal antibodies used for the detection of hexokinase II and glycogen synthase were generous gifts from Dr. O. Pedersen (Steno Memorial Hospital, Gentofte, Denmark). Each polyclonal antibody was generated by immunising rabbits with a synthetic peptide homologous to the last nine amino acids in the $\mathrm{COOH}$-terminus of the respective protein. [25, 26]. GLUT4 protein expression was assessed using a polyclonal antibody raised against the COOH-terminal peptide of GLUT4 (Biogenesis, Poole, UK), diluted in a ratio of 1:1000 in phosphate-buffered saline ( $\mathrm{pH}$ 7.4) containing $1 \%$ milk. Membranes were washed in TBST $(10 \mathrm{mmol} / \mathrm{l}$ TRIS, $140 \mathrm{mmol} / \mathrm{l}$ $\mathrm{NaCl}, 0.02 \%$ Tween 20, $\mathrm{pH} 7.6$ ), incubated with appropriate secondary antibody and washed in TBST. Proteins were made visible by enhanced chemiluminescence and quantified by densitometry.
Preparation of nuclear extracts. Nuclear extracts from gastrocnemius skeletal muscle were prepared as previously described [27] with minor modifications. Tissues were pulverised in liquid nitrogen and homogenised in 10 volumes $(w t / v)$ of buffer A (250 mmol/l sucrose, $10 \mathrm{mmol} / \mathrm{l} \mathrm{HEPES,} \mathrm{pH} \mathrm{7.6,} 25 \mathrm{mmol} / \mathrm{l}$ $\mathrm{KCl}, 1 \mathrm{mmol} / 1 \mathrm{EDTA}, 10 \%$ glycerol, $0.15 \mathrm{mmol} / \mathrm{l}$ spermine, $0.1 \mathrm{mmol} / \mathrm{l} \mathrm{PMSF}, 2 \mu \mathrm{g} / \mathrm{ml}$ each aprotinin, leupeptin, and pepstatin $\mathrm{A}$, and $6 \mu \mathrm{g} / \mathrm{ml}$ each L-1-tosylamido-2-phenylethyl chloromethyl ketone and 1-chloro-3-tosylamido-7-amino-2-heptanone) with 20 strokes of Pellet Pestle (Kebo Lab, Sweden) in the Eppendorf tubes and filtered through the gauze. The homogenate was centrifuged $10 \mathrm{~min}$ at $3900 \cdot \mathrm{g}$ at $4{ }^{\circ} \mathrm{C}$. The pellet was resuspended in $1 \mathrm{ml}$ of buffer $\mathrm{A}$ and homogenised $10 \mathrm{~s}$ by a Pellet Pestle with motor. The homogenate was layered over one-half volume of buffer B (1 mol/l sucrose, $10 \mathrm{mmol} / \mathrm{l} \mathrm{HE}$ PES, pH 7.6, $25 \mathrm{mmol} / \mathrm{l} \mathrm{KCl,} 1 \mathrm{mmol} / \mathrm{l}$ EDTA, $10 \%$ glycerol, $0.15 \mathrm{mmol} / \mathrm{l}$ spermine, $0.1 \mathrm{mmol} / 1 \mathrm{PMSF}, 2 \mu \mathrm{g} / \mathrm{ml}$ each aprotinin, leupeptin, and pepstatin A, and $6 \mu \mathrm{g} / \mathrm{ml}$ each L-1-tosylamido-2-phenylethyl chloromethyl ketone and 1-chloro-3-tosylamido-7-amino-2-heptanone) and centrifuged at $3900 \cdot \mathrm{g}$ for $10 \mathrm{~min}$ at $4{ }^{\circ} \mathrm{C}$. The pellet was resuspended in buffer $\mathrm{A} / \mathrm{glycerol}$ $(9: 1, w / w)$ and layered over one-third volume of buffer B/glycerol $(9: 1, w / w)$. The gradient was centrifuged at $48000 \cdot \mathrm{g}$ for $30 \mathrm{~min}$ at $4{ }^{\circ} \mathrm{C}$. The semi-purified nuclear pellet was resuspended in $100 \mu \mathrm{l}$ of nuclear extraction buffer $(10 \mathrm{mmol} / \mathrm{l} \mathrm{HE}$ PES, pH 7.6, $400 \mathrm{mmol} / \mathrm{l} \mathrm{KCl}, 3 \mathrm{mmol} / \mathrm{l} \mathrm{MgCl}_{2}, 0.1 \mathrm{mmol} / \mathrm{l}$ EDTA, $10 \%$ glycerol, $1 \mathrm{mmol} / \mathrm{l}$ DTT, $0.1 \mathrm{mmol} / \mathrm{l} \mathrm{PMSF}) . \mathrm{Nu}-$ clear proteins were extracted on ice for $30 \mathrm{~min}$ and the samples were centrifuge at $13000 \cdot \mathrm{g}$ for $10 \mathrm{~min}$ at $4{ }^{\circ} \mathrm{C}$. The supernatant was diluted four times in nuclear extraction buffer omitting $\mathrm{KCl}$, assayed for total protein using a Bradford assay kit (Bio-Rad) and stored at $-70^{\circ} \mathrm{C}$.

Electrophoretic Mobility Shift Assay. The myocyte enhancer factor 2 (MEF2) DNA-binding site oligonucleotide was commercially prepared (Santa Cruz Biotechnology, Santa Cruz, Calif., USA). The oligonucleotide was end-labelled with T4 polynucleotide kinase. The probes $(0.5 \mathrm{ng})$ were incubated with $2 \mu \mathrm{g}$ of nuclear extracts in a $20-\mu \mathrm{l}$ reaction containing $1 \mu \mathrm{g}$ poly $(\mathrm{dI}-\mathrm{dC}), 40 \mathrm{mmol} / \mathrm{l} \mathrm{KCl}, 5 \mathrm{mmol} / \mathrm{l} \mathrm{MgCl} 2,15 \mathrm{mmol} / \mathrm{l}$ HEPES, pH 7.9, $1 \mathrm{mmol} / \mathrm{l}$ EDTA, $0.5 \mathrm{mmol} / \mathrm{l}$ DTT, and $5 \%$ glycerol for $20 \mathrm{~min}$ at room temperature. For competition studies, the extract was pre-incubated with a 10 -fold molar excess of unlabeled oligonucleotide for $5 \mathrm{~min}$ before addition of radiolabelled probe. The samples were processed $(200 \mathrm{~V}$ for $2 \mathrm{~h} 4{ }^{\circ} \mathrm{C}$ ) on a non-denaturing $6 \%$ polyacrylamide ( $38: 1$ acrylamide/bisacrylamide) gel buffered with TRIS borate/EDTA (TBE, $22 \mathrm{mmol} / \mathrm{l} \mathrm{TRIS,} 22 \mathrm{mmol} / \mathrm{l}$ boric acid, and $0.5 \mathrm{mmol} / 1$ EDTA). The dried gels were exposed to PhosphoImager.

Statistics. Data are presented as means \pm SEM. Statistical differences were determined by a two-way analysis of variance (ANOVA) for treatment-effect on blood glucose and glucose tolerance, and by a one-way ANOVA for glucose transport, biochemical analysis and protein expression studies. When the ANOVA resulted in a significant F-ratio $(p<0.05)$, the location of the significance was determined with the FisherLSD test. A $p$ value of less than 0.05 was considered to be statistically significant.

\section{Results}

Short-term effect of AICAR on blood glucose. One hour after the AICAR injection (Fig.1A), blood glucose concentrations in $o b / o b$ mice were normalised 


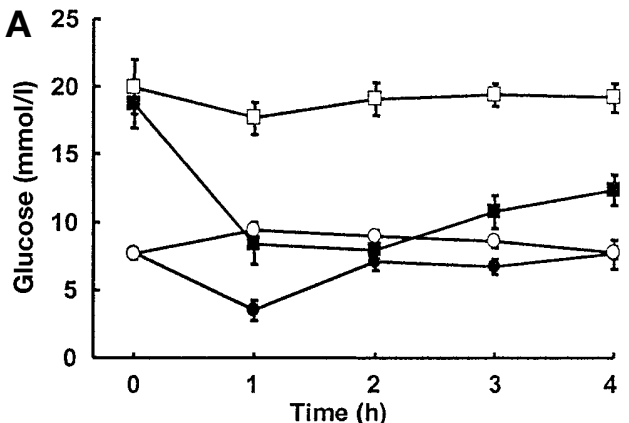

B
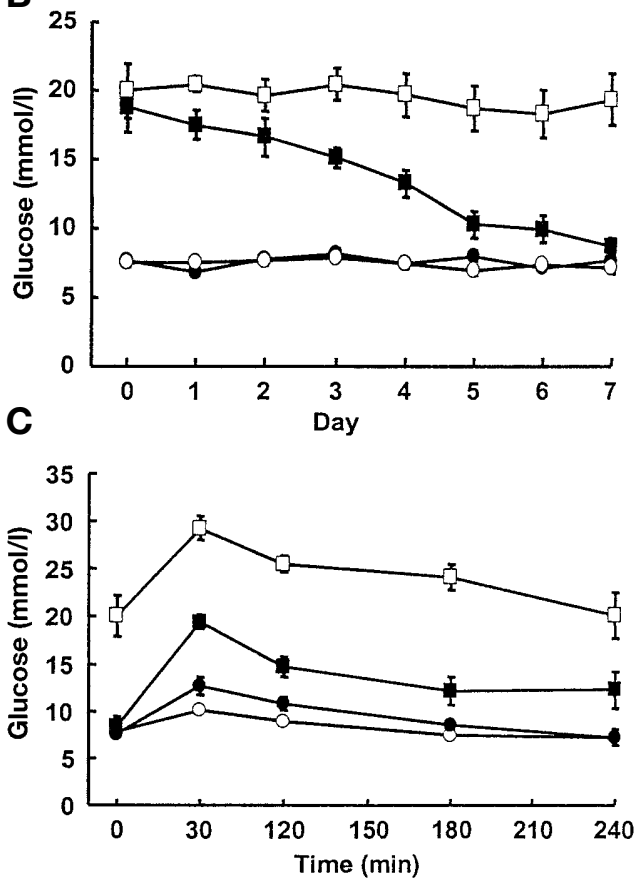

Fig. 1. Antidiabetic efficacy of subcutaneous injection of AICAR in $8-10$ weeks $o b / o b$ or lean mice. A Acute glucose lowering effect by AICAR. AICAR $(\boldsymbol{Q}, \mathbf{O})\left(1 \mathrm{mg} \cdot \mathrm{g}_{\left.\text {body } \mathrm{wt}^{-1}\right)}\right.$ or vehicle $(\square, \bigcirc)$ was given to lean $(\mathbf{O}, \bigcirc)$ or $o b / o b(\square, \square)$ mice by a subcutaneous injection. B Long-term glucose lowering effect by AICAR. AICAR ( $1 \mathrm{mg} \cdot \mathrm{g}$ body wt) or vehicle was given by a subcutaneous injection for 7 days. C Effect of long-term AICAR-treatment on glucose tolerance. Mice were treated with AICAR or vehicle for 7 days. Glucose tolerance was measured $24 \mathrm{~h}$ after the last day of treatment. Results are Means \pm SEM for $n=4-10$ mice

$(8.4 \pm 1.5$ vs $9.4 \pm 0.3 \mathrm{mmol} / \mathrm{l}$ for AICAR-treated $o b /$ $o b$ vs control mice, N.S.). The effect of AICAR in lowering glucose in $o b / o b$ mice was maintained for at least $4 \mathrm{~h}$. In lean mice, blood glucose concentrations were decreased within $1 \mathrm{~h}$ after AICAR injection $(7.7 \pm 0.4$ vs $2.8 \pm 0.4 \mathrm{mmol} / 1$ for untreated vs treated lean mice; $p<0.01)$, and were normalised by $2 \mathrm{~h}(7.5 \pm 1.4 \mathrm{mmol} / \mathrm{l})$.

Antidiabetic efficacy of 7-day AICAR-treatment. Long-term AICAR treatment corrected hyperglycaemia in $o b / o b$ mice, with a partial normalisation after 5 days $(18.7 \pm 1.8$ vs $13.3 \pm 1.0 \mathrm{mmol} / \mathrm{l}$ for before vs 5 days of daily treatment in $o b / o b p<0.001$ ) (Fig.1B). Complete normalisation of blood glucose concentrations was achieved between 5 and 7 days of the treatment regime. Treatment with AICAR (7 days) had no effect on fed glucose concentrations in lean mice.

Effect of 7-day AICAR treatment on glucose tolerance. Twenty-four hours after the last injection, an OGTT was done (Fig.1C). Treatment with AICAR did not alter glucose tolerance in lean mice. However, in $o b / o b$ mice, AICAR-treatment improved glucose tolerance (area under the curve [AUC], $2463 \pm 192$ vs $4,374 \pm 248 \mathrm{mmol} / 1 \cdot \mathrm{min}^{-1}$ for treated vs untreated $o b / o b$ mice, $p<0.001)$.

Animal characteristics and blood chemistry in AI$C A R$-treated and vehicle-treated (7-day) mice. Longterm (7 day) AICAR treatment did not alter body weight or fat mass in either lean or $o b / o b$ mice (Table 1). Furthermore plasma concentrations of ALAT, a clinical marker of liver damage, were not altered by AICAR treatment in either lean or $o b / o b$ mice. $O b / o b$ mice are characterised by advanced hyperinsulinaemia. Despite the mild suppression $(25 \%)$ of plasma insulin concentrations after longterm AICAR treatment ( $p=0.15$ vs vehicle-treated $o b / o b$ mice), the $o b / o b$ mice showed profound hyperinsulinaemia. Higher amounts of NEFA and triglyceride concentrations, also characteristic of the $o b / o b$ phenotype, were not improved by AICAR treatment. Rather, AICAR treatment increased plasma NEFA concentrations 1.6-fold in lean $(p=0.09)$ and 1.7fold in $o b / o b(p=0.03)$ mice and triglyceride concentrations 1.7 -fold in $o b / o b$ mice $(p=0.01)$.

Glycogen content in liver and gastrocnemius muscle after 7-day AICAR-treatment. Liver glycogen content was similar vehicle and AICAR-treated fasted and fed lean mice (Fig. 2A). In $o b / o b$ mice, AICAR-treatment increased liver glycogen content $50 \%$ under fed $(p<0.001)$ and $70 \%(p=0.01)$ under fasted conditions. Glycogen content in gastrocnemius muscle was similar in fed vehicle-treated lean and $o b / o b$ mice (Fig. 2B). Treatment with AICAR had no effect on fed muscle glycogen in either genotype. In vehicletreated mice, fasting reduced muscle glycogen content $17 \%(p=0.06)$ and $34 \%(p=0.04)$ in lean and $o b / o b$ mice, respectively compared with corresponding fed mice. Interestingly, AICAR treatment prevented the fasting-induced decrease in muscle glycogen content in both lean and $o b / o b$ mice.

Triglyceride content in gastrocnemius muscle and liver after 7-day AICAR-treatment. Triglyceride content in skeletal muscle from fed lean and $o b / o b$ mice was similar (Table 2). Long-term (7 day) AICAR-treatment led to a $22 \%$ increase in triglyceride content in 

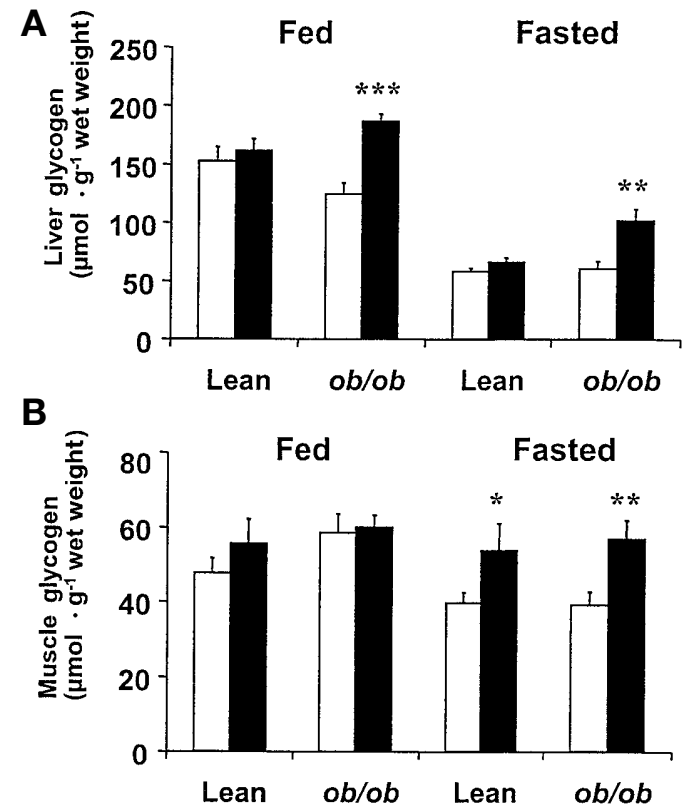

Fig. 2. Effect of long-term in vivo AICAR treatment on glycogen content in liver and skeletal muscle from fed and fasted mice. Lean and $o b / o b$ mice were treated with vehicle $(\square)$ or AICAR ( $\mathbf{\square})$ for 7-days as described. Liver (A) and gastrocnemius muscle (B) were obtained from fed and fasted mice and glycogen content was measured. Values are expressed as $\mu \mathrm{mol} \cdot \mathrm{g}$ wet weight ${ }^{-1}$. Results are Means \pm SEM for $n=$ 6-10 mice. ${ }^{*} p<0.05, * * p<0.01,{ }^{* * *} p<0.001$, significantly different from corresponding vehicle-treated mice

skeletal muscle from fed $o b / o b$ mice $(p<0.05)$, with no effect noted in lean mice. Vehicle and AICARtreated mice were also studied after an overnight fast. Fasting did not alter skeletal muscle triglyceride content in lean mice. In contrast with the fed mice, AICAR treatment promoted a $16 \%$ increase $(p<0.05)$ in skeletal muscle triglyceride content in fasting lean mice. In $o b / o b$ mice, fasting was associated with a $76 \%(p<0.05$ vs fed $o b / o b$ mice $)$ increase in skeletal muscle triglyceride content; this effect was not altered by treatment with AICAR. Liver triglyceride content was $21 \%$ greater $(p<0.05)$ in fed $o b / o b$ than lean mice. Treatment with AICAR did not alter liver triglyceride in fed lean mice but was effective in normalising liver triglyceride content in fed

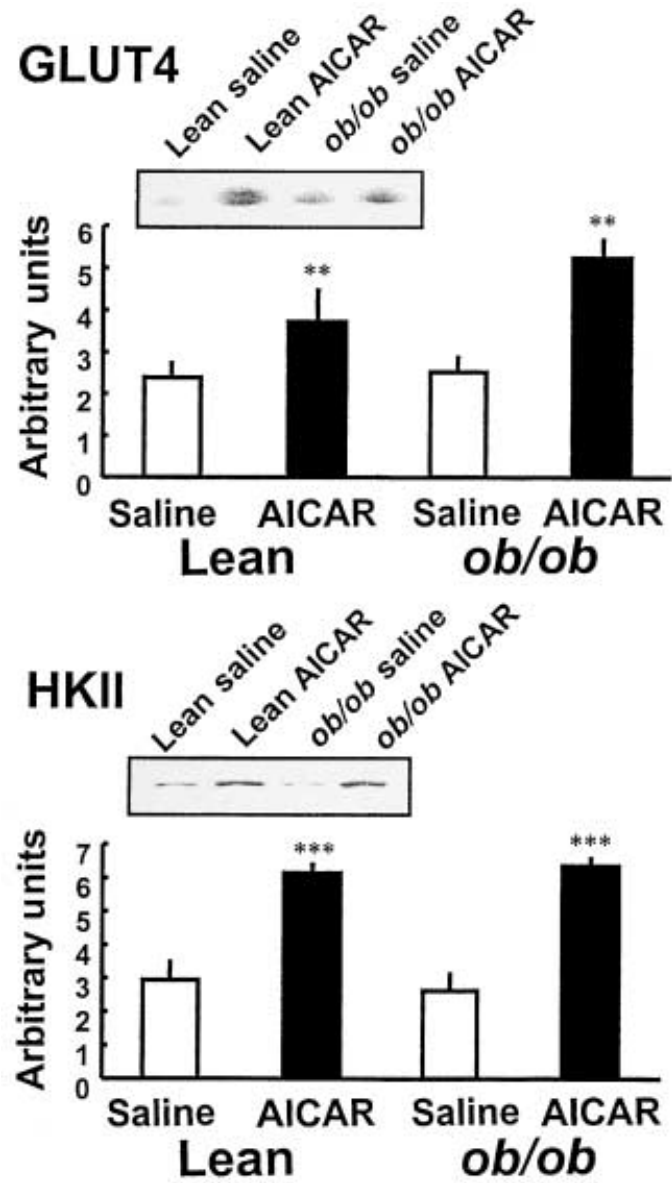

Fig.3. Effect of long-term in vivo AICAR treatment on GLUT4 and hexokinase II expression in skeletal muscle. Lean and $o b / o b$ mice were treated with vehicle $(\square)$ or AICAR (ם) for 7 days as described. Gastrocnemius muscle was obtained from fed mice and GLUT4 (A) and Hexokinase II (B) was determined. Inset is representative immunoblot. Graph is Means \pm SEM arbitrary units for $n=5$ mice. $* * p<0.01$, $* * * p<0.001$, significantly different from vehicle-treated mice

$o b / o b$ mice. In fasted mice, liver triglyceride content was similar between untreated and treated lean and $o b / o b$ mice.

Effect of 7-day AICAR treatment on GLUT4 and hexokinase II protein expression. Protein expression of GLUT4, hexokinase II and glycogen synthase, re-

Table 1. Mice characteristics and blood chemistry

\begin{tabular}{lllcc}
\hline & Lean vehicle & Lean AICAR & $o b / o b$ vehicle & $o b / o b$ AICAR \\
\hline Body wt $(\mathrm{g})$ & $21.7 \pm 0.9$ & $23.3 \pm 0.8$ & $41 \pm 1.5$ & $40.7 \pm 0.8$ \\
Fat pad wt $(\mathrm{g})$ & $0.27 \pm 0.04$ & $0.26 \pm 0.04$ & $2.75 \pm 0.20$ & $2.48 \pm 0.13$ \\
Insulin $(\mathrm{ng} / \mathrm{ml})$ & $0.56 \pm 0.21$ & $0.44 \pm 0.07$ & $52.91 \pm 10.33$ & $39.81 \pm 6.20$ \\
NEFA $(\mu \mathrm{mol} / \mathrm{l})$ & $247 \pm 46$ & $393 \pm 72$ & $429 \pm 33$ & $741 \pm 69^{* *}$ \\
Triglyceride $(\mathrm{mmol} / \mathrm{l})$ & $1.5 \pm 0.24$ & $1.55 \pm 0.25$ & $2.27 \pm 0.36$ & $3.76 \pm 0.76^{*}$ \\
ALAT $(\mu \mathrm{kat} / \mathrm{l})$ & $<0.01^{c}$ & $<0.01^{\mathrm{a}}$ & $3.19 \pm 0.32$ & $2.90 \pm 0.57$
\end{tabular}

Blood samples were obtained in fed mice $(n=6)$. Results are

Means \pm SEM

$* p<0.05$

$* * p<0.01$ vs vehicle-treated $o b / o b$ mice

${ }^{a}$ Below the detection limit of the assay 


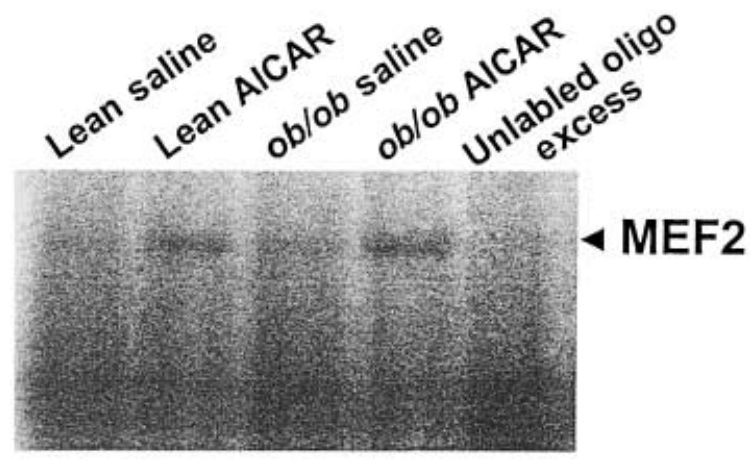

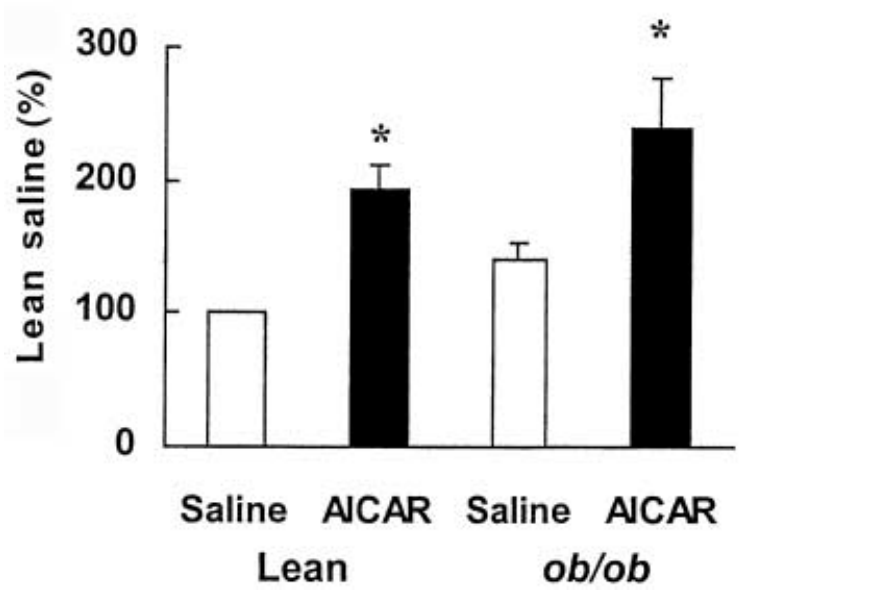

Fig.4. Effects of long-term in vivo AICAR treatment on MEF2 activation. A representative autoradiogram is shown (A), and the quantitative data (Means \pm SEM) from four experiments are shown (B). ${ }^{*} p<0.05$ vs lean vehicle-treated mice

spectively, were similar between lean and $o b / o b$ mice. Regardless of genotype, AICAR-treatment was associated with a two-fold increase protein expression of GLUT4 $(p<0.01)$ and hexokinase II $(p<0.001)$ (Fig. 3), and no change in glycogen synthase protein content in skeletal muscle (data not shown).

Effect of 7-day AICAR treatment on MEF2 DNA binding. Using a consensus MEF2 double-stranded oligonucleotide, we observed a specific decrease in the mobility of the labelled probe in nuclear extracts from gastrocnemius skeletal muscles (data not
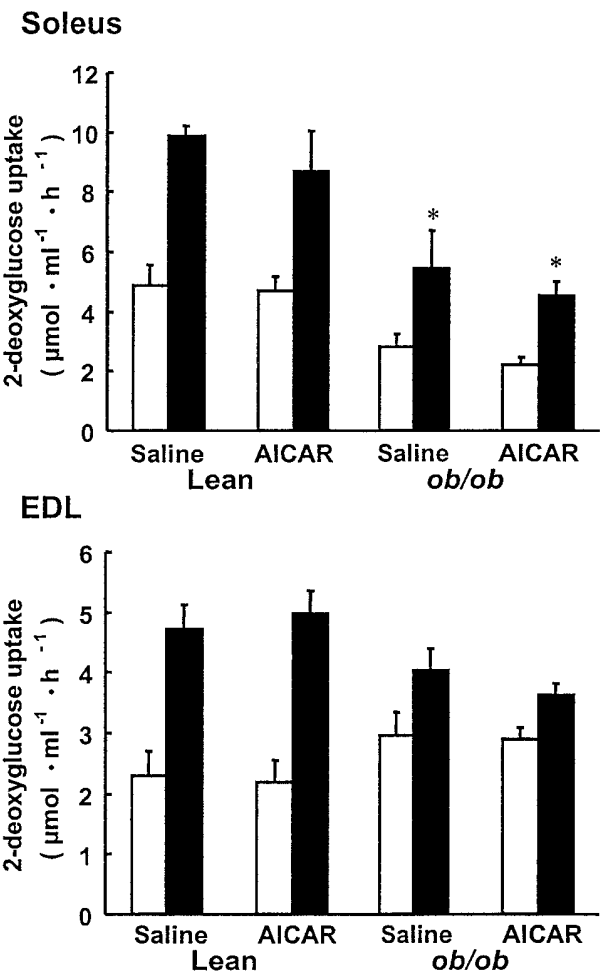

Fig. 5. Effect of long-term in vivo AICAR treatment on insulin-stimulated glucose uptake in isolated skeletal muscle. Soleus (A) and EDL (B) muscle were excised $24 \mathrm{~h}$ after the last treatment from fed mice and incubated without (Basal, $\square$ ) or with $120 \mathrm{nmol} / \mathrm{l}$ insulin ( $\boldsymbol{\square}$ ). The 2-deoxyglucose uptake was assessed. Results are Means \pm SEM for 4 muscles. ${ }^{*} p<0.05$, significantly different from lean mice

shown). In nuclear extracts isolated from AICARtreated lean and $o b / o b$ mice, the MEF2-DNA complex band was $(p<0.05)$ enhanced compared with lean control (1.9-fold and 2.4-fold for AICAR-treated lean and $o b / o b$ mice, respectively) (Fig. 4). Binding activity was specifically blocked in the presence of a 10-fold molar excess of unlabelled oligonucleotide corresponding to the MEF2 probe.

Effect of 7-day AICAR treatment on insulin-stimulated glucose uptake. Insulin-stimulated glucose uptake was impaired in skeletal muscle from $o b / o b$ mice

Table 2. Triglyceride content in gastrocnemius muscle and liver from fed or fasted lean and $o b / o b$ mice $24 \mathrm{~h}$ after 7 -day (long-term) AICAR-treatment

\begin{tabular}{|c|c|c|c|c|c|c|}
\hline \multirow[b]{2}{*}{ Group } & \multicolumn{3}{|c|}{ Muscle triglyceride $\mu \mathrm{mol} \cdot \mathrm{g}$ wet $\mathrm{wt}^{-1}$} & \multicolumn{3}{|c|}{ Liver triglyceride $\mu \mathrm{mol} \cdot \mathrm{g}$ wet $\mathrm{wt}^{-1}$} \\
\hline & Fed & Fasted & $\% \Uparrow$ & Fed & Fasted & $\% \Uparrow$ \\
\hline Lean vehicle & $14.0 \pm 1.3$ & $14.2 \pm 1.9$ & $1 \%$ & $68.0 \pm 3.2$ & $55.6 \pm 3.1 *$ & $18 \%$ \\
\hline$o b / o b$ vehicle & $14.4 \pm 0.6$ & $25.3 \pm 4.9^{*}$ & $76 \%$ & $82.2 \pm 5.8$ & $58.7 \pm 6.6^{* *}$ & $29 \%$ \\
\hline$o b / o b$ AICAR & $17.5 \pm 0.8 * * *$ & $29.2 \pm 3.3 * *$ & $67 \%$ & $61.8 \pm 4.7 * * * *$ & $54.8 \pm 10.8$ & $11 \%$ \\
\hline
\end{tabular}




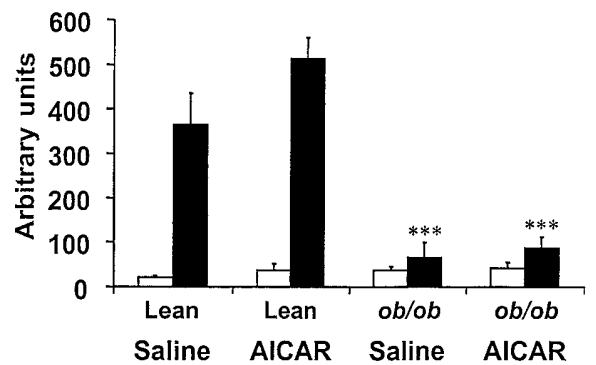

Fig. 6. Effect of long-term in vivo AICAR treatment on insulin-stimulated phospho-tyrosine-associated PI 3-kinase activity in isolated skeletal muscle. Incorporation of $\left[{ }^{32} \mathrm{P}\right]$ into PI 3-phosphate for basal $(\square)$ or insulin-stimulated ( $\square$ ) muscle was assessed. Results are Means \pm SEM arbitrary PhosphoImager units for 4 muscles. $* * * p<0.001$, significantly different from lean mice

compared with lean mice (Fig 5). In soleus muscle, insulin-stimulated glucose uptake was about $45 \%$ lower in $o b / o b$ mice $(p<0.05)$. While the absolute insulin-stimulated glucose transport was not significantly impaired in EDL muscle from $o b / o b$ mice, the foldinsulin-stimulation (increase over basal) was greater in lean than in $o b / o b$ mice (2.0-fold vs 1.4 -fold, respectively). Similar defects were noted in soleus and EDL muscle from fasted mice (data not shown). Treatment with AICAR did not improve basal or insulin-stimulated glucose uptake in either soleus or EDL muscle from lean or $o b / o b$ mice. A similar insulin-stimulated response was noted in soleus and EDL muscle from fasted vehicle compared with AICARtreated mice (data not shown).

Effect of 7-day AICAR treatment on insulin-stimulated PI 3-kinase activity. Insulin-stimulated PI 3-kinase activity was severely impaired in soleus muscle from $o b / o b$ mice (Fig. 6). In lean mice, insulin increased anti-phosphotyrosine-associated PI 3-kinase activity 10 -fold $(p<0.001)$ in soleus muscle whereas, in $o b /$ $o b$ mice, the insulin effect was severely blunted $(82 \%$ lower; $p<0.001)$ compared with vehicle-treated lean mice.

Effect of short-term in vitro insulin or AICAR exposure or both on glucose uptake in isolated skeletal muscle from untreated mice. AICAR $(2 \mathrm{mmol} / \mathrm{l})$ increases glucose uptake in soleus and EDL muscle from lean mice (Fig.7). The magnitude of AICARsimulated glucose uptake was similar to that achieved by a maximal effective concentration of insulin. Furthermore, AICAR and insulin elicited an additive effect on glucose uptake in both muscle types. In $o b / o b$ mice, insulin-stimulated glucose uptake was severely blunted in soleus ( $45 \%)$ and moderately reduced in EDL (10\%) muscle compared with lean mice $(p<0.05)$. The AICAR-stimulated glucose uptake was completely normal, with similar values achieved
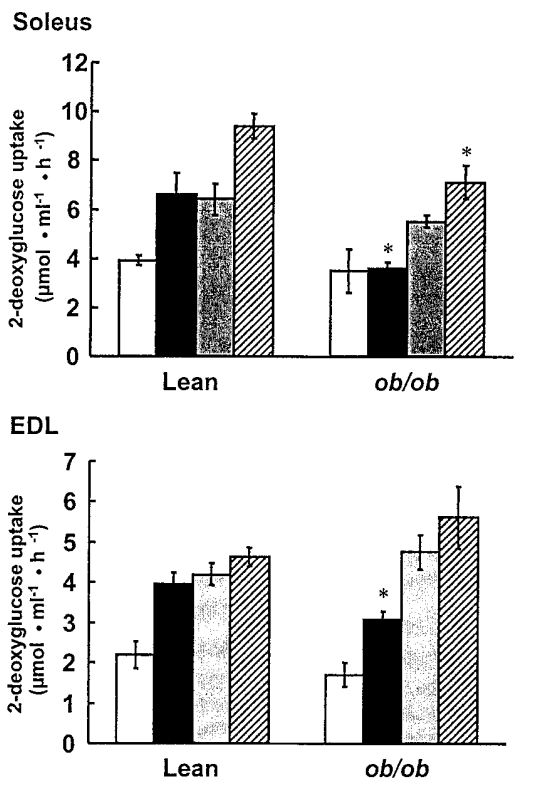

Fig. 7. In vitro effect of insulin or AICAR or both on glucose uptake in isolated skeletal muscle. Soleus (A) or EDL (B) muscle from lean or $o b / o b$ mice was incubated in the absence (Basal, $\square$ ) or presence of insulin $(120 \mathrm{nmol} / \mathrm{l} ; \mathbf{\square})$, AICAR ( $2 \mathrm{mmol} / \mathrm{l}$; $\mathrm{X})$, or a combination (19) of insulin $(120 \mathrm{nmol} / \mathrm{l})$ and AICAR ( $2 \mathrm{mmol} / \mathrm{l})$. Results are Means \pm SEM for 4 muscles. ${ }^{*} p<0.05, * * p<0.001$, significantly different from lean mice

between lean and $o b / o b$ mice. Insulin and AICAR elicited additive effects on glucose uptake in $o b / o b$ mice.

\section{Discussion}

This study provides evidence that chronic AICAR treatment lowers blood glucose and improves glucose tolerance in diabetic $o b / o b$ mice. The effect of AICAR in lowering blood glucose appears to occur from a direct stimulatory (insulin-independent) effect on glucose transport in skeletal muscle and from an inhibition of hepatic glucose production, presumably by inhibiting hepatic gluconeogenesis. However, $o b / o b$ mice are an extreme model of obesity, because of their lack of the hormone leptin and consequently do not mirror ordinary human obesity [28]. The lack of leptin production, or the severe obesity or both, could mean that these mice do not respond to AICAR treatment in the way humans with diabetes would.

AICAR treatment in $o b / o b$ mice was associated with higher amounts of liver glycogen under both fasting and fed conditions. Liver glycogen content was $50 \%$ and $70 \%$ greater in fed and fasted AICAR treated than untreated mice. Our data does not exclude the possibility that chronic AICAR treatment has an inhibitory effect on gluconeogenesis. In isolated hepatocytes prepared from fasted rats, AICAR 
treatment, after its conversion into AICAribotide or ZMP, exerts a dose-dependent inhibition on fructose-1, 6 -bisphosphatase and hence on gluconeogenesis, an effect which is not dependent on AMPK [20, 29]. In both fasted and fed mice, a single AICAR injection $(250 \mathrm{mg} / \mathrm{kg})$ led to a significant accumulation of fructose-1, 6-bisphosphate, reflecting inhibition of fructose-1, 6-bisphosphatase and gluconeogenesis [20]. In addition, treatment of hepatoma cells with AICAR mimics the effect of insulin to repress gene transcription of PEPCK and glucose-6-phosphatase, two key gluconeogenetic genes [30]. The reduced blood glucose concentrations in AICAR-treated $o b /$ $o b$ mice in this study can probably be explained by a marked inhibition of hepatic glucose output. Previous studies indicate that an effect on hepatic glucose output after AICAR treatment could be attributed to an inhibition of liver gluconeogenesis [20, 29, 30].

The increased liver glycogen content in AICARtreated $o b / o b$ mice in our study could be due to either a marked inhibition of hepatic glycogen breakdown or to an increased glycogen formation, or to both. Intriguingly, AICAR treatment did not alter liver glycogen content in lean mice. The reason for this is not clear, but it is possible that AICAR can only exert a positive effect when liver glucose metabolism is impaired (i.e. there is increased hepatic glucose production).

Although AICAR treatment did lower blood glucose in $o b / o b$ mice, this cannot be attributed to persistent improvements in insulin-stimulated glucose uptake in skeletal muscle. Nevertheless, AICAR treatment increased protein expression of GLUT4 and hexokinase II, with no change in glycogen synthase noted. Importantly, in vitro MEF2 sequence specific binding activity increased in skeletal muscle from lean and $o b / o b$ mice after 7 days of AICAR treatment. The MEF2 site seems to be essential for GLUT4 expression because deletions or point mutations within the MEF2 consensus binding sequence of the human GLUT4 promoter completely prevent tissue-specific and hormonal/metabolic regulation of GLUT4 protein [31]. Overexpression of either GLUT4 or hexokinase II in transgenic mice is associated with increased glucose uptake and metabolism in skeletal muscle $[32,33]$. Thus, our results suggest that AICAR-treatment was not effective in correcting the defective insulin signal transduction to glucose transport that is characteristic of $o b / o b$ mice $[28,34]$. The PI 3-kinase is a necessary component of the insulin signal transduction pathway to glucose transport $[35,36]$ and a site of insulin resistance in skeletal muscle in $o b / o b$ mice [28, 34]. AICAR-treatment did not restore insulin-stimulated phosphotyrosine-associated PI 3-kinase activity in soleus muscle from $o b / o b$ mice. Thus, the effect of chronic AICAR treatment on blood glucose concentrations and glucose tolerance in diabetic $o b / o b$ mice cannot be at- tributed to long-term improvements in insulin action on PI 3-kinase and glucose transport in skeletal muscle.

Short-term in vitro AICAR treatment increased glucose transport in isolated skeletal muscle from diabetic $o b / o b$ mice, despite severe insulin resistance. This is in accordance with previous studies reporting short-term direct effects of AICAR on glucose transport and uptake into skeletal muscle from non-diabetic rodents $[9,14,16,17]$. Our findings have important clinical implications, suggesting that signal transduction by the AMPK pathway to glucose transport is normal in insulin resistant muscle. Although insulin action was not improved after 7 days of treatment with AICAR, each injection could have elicited a transient, short-term insulin-independent effect on skeletal muscle glucose transport, which collectively resulted in a chronic blood glucose lowering effect in $o b / o b$ mice. Thus, activation of glucose transport by the AMPK pathway provides an alternative strategy to bypass signalling defects characteristic of insulin resistant skeletal muscle.

Despite the beneficial effect of AICAR treatment on glucose homeostasis, the blood lipid profile in $\mathrm{ob} /$ $o b$ mice deteriorated. Circulating amounts of NEFA and triglyceride were increased in diabetic mice following 7-days of AICAR treatment. Because AICAR treatment inhibits lipogenesis through increased phosphorylation of acetyl-CoA carboxylase [37], these deleterious effects of AICAR on the blood lipid profile are not surprising. Increased plasma NEFA is probably due to increased lipolysis in adipocytes. Short-term (60 min) AICAR exposure in isolated adipocytes inhibits isoprenaline-stimulated lipolysis, without any significant direct effect $[10,37]$. Activation of AMPK by AICAR is known to phosphorylate and inhibit acetyl CoA carboxylase, leading to a decrease in malonyl $\mathrm{CoA}$ and an increase in fatty acid oxidation $[38,39]$. In this study, amounts of triglyceride decreased in liver and increased in skeletal muscle in fed mice and did not change in fasted mice after 7-day AICAR treatment. However, we cannot exclude the possibility that AICAR-treatment could also increase triglyceride turnover rate in these tissues.

Activation of the AMPK signalling system has been proposed as a method of treatment for patients with impaired glucose tolerance and Type II diabetes mellitus [13]. To date, the most widely used activator of this pathway is AICAR, which through conversion to ZMP, mimics effects of AMP on AMPK [9-12]. Despite major differences between $o b / o b$ mice and human obesity, we noted several positive effects of AICAR-including improved glucose homeostasis, increased muscle GLUT4 and hexokinase II protein expression. We also noted a glycogen sparing/enhancing effect in liver and muscle, improved glucose uptake in isolated skeletal muscle after short-term in 
vitro exposure. However, AICAR treatment had adverse effects on the blood lipid profile in both normal and $o b / o b$ mice. Furthermore, a recent report [40] provides evidence that in 3T3-L1 adipocytes, a 60 min AICAR exposure inhibits insulin-stimulated glucose transport.

Because large amounts of AICAR are needed to induce the adaptations we describe, AICAR itself will probably not be used in the treatment of metabolic abnormalities patients with Type II diabetes mellitus. Our study highlights the importance of evaluating compounds that mimic the effects of AICAR in whole body systems. For AMPK to be an acceptable target for anti-diabetic treatment, tissue-specific and pathway-specific pharmacological strategies must be developed to stop the blood lipid profile worsening.

Acknowledgements. This study was supported by grants from the Swedish Medical Research Council, the Swedish Diabetes Association, the Foundation for Scientific Studies of Diabetology, the Swedish National Centre for Research in Sports and from the following Research Foundations: Thurings, Wibergs, Magnus Bergwalls, Tore Nilsons, Novo-Nordisk and Marcus and Amalia Wallenberg.

\section{References}

1. Deckert T, Poulsen JE, Larsen M (1978) Prognosis of diabetics with diabetes onset before the age of 31. I. Survival, causes of death, and complications. Diabetologia 14: 363-370

2. Siedell JC (2000) Obesity, insulin resistance and diabetes: a worldwide epidemic. Br J Nutr 83 [Suppl 1]: S5-S8

3. Van den Arend IJ, Stolk RP, Krans HM, Grobbee DE, Schrijvers AJ (2000) Management of type 2 diabetes: a challenge for patient and physician. Patient Educ Couns 40: $187-194$

4. Turner RC, Cull CA, Frighi V, Holman RB (1999) Glycemic control with diet, sulfonylurea, metformin, or insulin in patients with type 2 diabetes mellitus. JAMA 281: 2005-2012

5. Zierath JR, Wallberg-Henriksson H (1992) Exercise training in obese diabetic patients. Sports Med 14: 171-189

6. American Diabetes Association (1998) Clinical practice recommendations. Diabetes mellitus and exercise. Diabetes Care 21 [Suppl. 1]: S41-S44

7. Samaras K, Ashwell S, Mackintosh A-M, Campbell VL, Chrisholm DJ (1996) Exercise in NIDDM: are we missing the point? Diabet Med 13: 780-781

8. Schneider SH, Khanchadurian AK, Amorosa LF, Clemow L, Ruderman NB (1992) Ten-year experience with an exercise-based outpatient life-style modification program in the treatment of diabetes mellitus. Diabetes Care 15 [Suppl 4]: $1800-1810$

9. Merrill GF, Kurth EJ, Hardie DG, Winder WW (1997) AICA riboside increases AMP-activated protein kinase, fatty acid oxidation, and glucose uptake in rat muscle. Am J Physiol Endocrinol Metab 273: E1107-E1112

10. Corton JM, Gillespie JG, Hawley SA, Hardie DG (1995) 5Aminoimidazole-4-carboxamide ribonucleoside: a specific method for activating protein kinase in intact cells? Eur $\mathrm{J}$ Biochem 229: 558-565
11. Henin N, Vincent MF, Gruber HE, Van den Berghe G (1995) Inhibition of fatty acid and cholesterol synthase by stimulation of AMP-activated protein kinase. FASEB J 9: 541-546

12. Henin N, Vincent MF, Van den Berghe G (1996) Stimulation of rat liver AMP-activated protein kinase by AMP analogues. Biochim Biophys Acta 1290: 197-203

13. Winder WW, Hardie DG (1999) AMP-activated protein kinase, a metabolic master switch: possible roles in Type 2 diabetes. Am J Physiol Endocrinol Metab 277: E1-E10

14. Hayashi T, Hirshman MF, Kuth EJ, Winder WW, Goodyear LJ (1998) Evidence for 5'-AMP-activated protein kinase mediation of the effect of muscle contraction on glucose transport. Diabetes 47: 1369-1373

15. Kurth-Kraczek E, Hirshman MF, Goodyear LJ, Winder WW (1999) 5' AMP-Activated protein kinase activation causes GLUT4 translocation in skeletal muscle. Diabetes 48: $1667-1671$

16. Bergeron R, Russell RR 3rd, Young LH et al. (1999) Effect of AMPK activation on muscle glucose metabolism in conscious rats. Am J Physiol Endocrinol Metabol 276: E938E944

17. Hayashi T, Hirshman MF, Fujii N, Habinowsk SA, Witters LA, Goodyear LJ (1999) Metabolic stress and altered glucose transport: activation of AMP-activated protein kinase as a unifying coupling mechanism. Diabetes 49: 527-531

18. Holmes BF, Kurth-Kraczek EJ, Winder WW (1999) Chronic activation of 5'-AMP-activated protein kinase increases GLUT4, hexokinase and glycogen in muscle. J Appl Physiol 87: 1990-1995

19. Ojuka EO, Nolte LA, Holloszy JO (2000) Increased expression of GLUT4 and hexokinase in rat epitrochlearis muscles exposed to AICAR in vitro. J Appl Physiol 88: 1072-1075

20. Vincent MF, Erion MD, Gruber HE, Van den Berghe G (1996) Hypoglycaemic effect of AICAriboside in mice. Diabetologia 39: 1148-1155

21. Hansen P, Gulve EA, Gao J, Schluter J, Mueckler MM, Holloszy JO (1995) Kinetics of 2-deoxyglucose transport in skeletal muscle. Effects of insulin and contractions. Am J Physiol Cell Physiol 259: C30-C35

22. Wallberg-Henriksson H, Zetan N, Henriksson J (1987) Reversibility of decreased insulin-stimulated glucose transport capacity in diabetic muscle with in vitro incubation. J Biol Chem 262: 7665-7671

23. Saad MJA, Folli F, Kahn JA, Kahn CR (1993) Modulation of insulin receptor, insulin receptor substrate-1, and phosphatidylinositol 3-kinase in liver and muscle of dexamethasone-treated rats. J Clin Invest 92: 2065-2072

24. Krook A, Whitehead JP, Dobson SP et al. (1997) Two naturally occurring insulin receptor tyrosine kinase domain mutants provide evidence that phosphatidylinositol 3-kinase activation alone is not sufficient for the meditation of insulin's metabolic and mitogenic effects. J Biol Chem 272: 30208-30214

25. Vestergaard H, Lund S, Larsen FS, Bjerrum OJ, Pedersen O (1993) Glycogen synthase and phosphofructokinase protein and mRNA levels in skeletal muscle from insulin-resistant patients with non-insulin-dependent diabetes mellitus. J Clin Invest 91: 2342-2350

26. Vestergaard H, Bjøjbæk C, Hansen T, Larsen FS, Granner DK, Pedersen O (1995) Impaired activity and gene expression of hexokinase II in muscle from non-insulin-dependent diabetes mellitus patients. J Clin Invest 96: 2639-2645

27. Mora S, Pessin JE (2000) The MEF2A isoform is required for striated muscle-specific expression of the insulin-responsive GLUT4 glucose transporter. J Biol Chem 275: 16323-16328 
28. Kerouz NJ, Horsch D, Pons S, Kahn CR (1997) Differential regulation of insulin receptor substrates-1 and -2 (IRS-1 and IRS-2) and phosphatidylinositol 3-kinase isoforms in liver and muscle of the obese diabetic (ob/ob) mouse. J Clin Invest 100: 3164-3172

29. Vincent MF, Marangos PJ, Gruber HE, Van den Berghe G (1991) Inhibition by AICA riboside of gluconeogenesis in isolated rat hepatocytes. Diabetes 40: 1259-1266

30. Lochhead PA, Salt IP, Walker KS, Hardie DG, Sutherland C (2000) 5-aminoimidazole-4-carboxamide riboside mimics the effect of insulin on the expression of the 2 keygluconeogenic genes PEPCK and glucose-6-phosphatase. Diabetes 49: 896-903

31. Thai M, Guruswamy S, Cao K, Pessin J, Olson A (1998) Myocyte enhancer factor 2 (MEF2)-binding site is required for GLUT4 gene expression in transgenic mice. Regulation of MEF2 DNA binding activity in insulin-deficient diabetes. J Biol Chem 273: 14285-14292

32. Ren J-M, Marshall BA, Gulve EA et al. (1993) Evidence from transgenic mice that glucose transport is rate limiting for glycogen deposition and glycolysis in skeletal muscle. J Biol Chem 268: 16113-16115

33. Chang P-Y, Jensen J, Printz RL, Granner DK, Ivy JI, Moller DE (1996) Overexpression of hexokinase II in transgenic mice. J Biol Chem 271: 14834-14839
34. Virkamäki A, Ueki K, Kahn CR (1999) Protein-protein interactions in insulin signaling and the molecular mechanisms of insulin resistance. J Clin Invest 103: 931-943

35. Cheatham B, Vlahos CJ, Cheatham L, Wang L, Blenis J, Khan CR (1994) Phosphatidylinositol 3-kinase is required for insulin stimulation of pp70 S6 kinase, DNA synthesis, and glucose transporter translocation. Mol Cell Biol 14: 4902-4911

36. Shepherd PR, Nave BT, Rincon J et al. (1997) Involvement of phosphoinositide 3-kinase in insulin stimulation of MAP-kinase and phosphorylation of protein kinase-B in human skeletal muscle: implications for glucose metabolism. Diabetologia 40: 1172-1177

37. Sullivan JE, Brocklehurst KJ, Marley AE, Carey F, Carling D, Beri RK (1994) Inhibition of lipolysis in isolated rat adipocytes with AICAR, a cell-permeable activator of AMP-activated protein kinase. FEBS Lett 353: 33-36

38. Hardie DG (1989) Regulation of fatty acid synthesis via phosphorylation of acetyl-CoA carboxylase. Prog Lipid Res 28: 117-146

39. Hardie DG, Carling D (1997) The AMP-activated protein kinase. Fuel gauge of the mammalian cell? Eur J Biochem 246: 259-273

40. Salt IP, Connell JMC, Gould GW (2000) 5-Aminoimidazole-4-carboxamide ribonucleoside (AICAR) inhibits insulin-stimulated glucose transport in 3T3-L1 adipocytes. Diabetes 49: 1649-1656 